\title{
The Day of the Son of Man and its anticipation (Luke 17:26-30)
}

\author{
Iulian Faraoanu \\ University "Alexandru Ioan Cuza", Iasi \\ Str. Vascauteanu 6, 700462 lasi, Romania \\ E-mail address: faraoanu@yahoo.com
}

\begin{abstract}
Keywords: eschatology, eating, drinking, judgment day, Noah and Lot, salvation.
\end{abstract}
\begin{abstract}
The aim of this paper is to focus on the biblical images in the text Luke 17:26-30. The verses Luke 17:26-30 describe the coming of the day of the Lord and the manner of waiting such a day. The evangelist offers an example of lack of preparation for the return of Christ, the Son of Man. The members of the lukan communities have a lot of the activities without connection to the spiritual life. First, Luke intends to condemn an immanent vision on life. Secondly, comes the lack of concern for the kingdom of God. The comparison with the days of Noah and Lot has exhortative function, inviting the members of Luke's community to focus their look and attention on the divine realities. In the conclusion, the delay of the Parousia should not lead to a life limited to the earthly activities, thus forgetting about God. The anticipation of Christ return must be alive, while being aware that the Lord may arrive at any moment, and His coming should find people prepared for it.
\end{abstract}

\section{INTRODUCTION}

The pericope in Luke 17:26-30 offers an image of the society in St. Luke's times, a society characterized by complexity and similarity to nowadays world. The activities performed by Luke's contemporaries indicate welfare and an existence focused excessively on earthly life. This was probably due to the influence of the Greek culture, which was prevailing at the time. As testimony to this type of existence is the presence of terms such as "eating and drinking", as well as the focus of the author on hospitality, associated with the feast.

This similarity between Luke's community and the contemporary society inspired the grounds for this study. The focus is on a lifestyle where the afterlife, preceded by the judgment at the second coming of Christ, is often overlooked. The awareness that the Lord will come unexpectedly should remove all temptation to forget God, replacing Him with the problems of the earthly existence.

The theme analyzed is connected to eschatology, especially to the speech on the Parousia. It is a well-known fact that the anticipation of the second coming of Christ exerted great influence on the ethics of the early Church. For the early Christians, the reference to the coming of the Lord represented a stimulus to lead a life consistent with the demands of the Gospel, with our attention on the afterlife.

\section{STRUCTURE OF THE TEXT IN LUKE 17:26-30}

Verses 27 and 28 of Luke 17:26-30 seem to represent the central part, focusing our attention on the actions of the contemporaries of Noah and Lot. Verses 28-30 are in parallelism with verses 26-27, the latter being considered by many scholars a literary unit in Q [1] source. Verse 27 continues and explains the statement of verse 26. Similarly, verse 28 is explained by verse 29 .

A surprising aspect is the large number of verbs, especially action verbs: there are ten action verbs in paratactic coordination [2], rendering seven types of activities.

Then, the repetition of the group of verbs "esthíô-pinô" (verses 27 and 28) indicate a certain interest of the author for this theme.

Based on these elements, the structure can be presented as follows. 
A. Just as it was in the days of Noah - so also will it be in the days of the Son of Man

B. In the days of Noah

1. Four verbs in the present continuous ("eating and drinking, marrying and giving in marriage").

2. Noah entered the ark.

3. The flood destroyed them all.

$B^{\prime}$. (It will be just like this on the day the Son of Man) It was the same in the days of Lot:

1. six verbs in the present continuous.

2. Lot left Sodom.

3. Fire and sulfur rained down from heaven and destroyed them all.

$A^{\prime}$. It will be just like this (as it was in the days of Noah) on the day of the Son of Man.

This hypothesis for the structure is not totally symmetrical. The author proposes two examples, with a central statement in verse 26. This verse contains the origin and the essence of all that follows. When reading the text, one notices at every step the confrontation between Noah's biblical time, Lot's biblical time ("as it was in the days") and the end of time ("it will be just like this on the day the Son of Man"). The initial statement is resumed at the end of the text; the expression "the Son of Man is revealed" is unique in the Gospel of Luke. [3]

An important function seems to have the "egheneto" aorist present in verses 26 and 28; the aorist evokes the two aspects of the Genesis - the one related to Noah and the one related to Lot. Then, there is a description of these biblical times, in three moments.

Considering the entire structure scheme, one can reach the following conclusions. First, the comparisons highlight the actions (in the present continuous) of the contemporaries of Noah and Lot. We notice that the author pays great attention to the reflection on the behavior of such people.

Secondly, the manner in which Noah and Lot are saved can be presented using two actions which seem to be in opposition: "to enter" and "to exit" [4]. Unlike the Genesis, only one person is saved here, - namely Noah, Lot, respectively. Probably, the author is interested not so much in the number of those saved, but rather in the paradigm of the one saved, who is in a privileged situation.

Finally, another side of judgment is described, with the presentation of the punishment of all those who did not act in accordance with God's will. It is surprising that, although there is no reference to sin, God is punishing. The very activities listed in verses 27 and 28 seem to be the cause of destruction of the people. It is probably a lifestyle focused on the earthly dimension, neglecting the divine realities [5].

Another thing to mention is the association between Noah and Lot, present in the Old Testament. The Book of Ecclesiasticus 64:10 refers to "destroyed nations", probably an allusion to the giants of Genesis 6:4. These giants will then be punished with the flood.

Still in verse 28 , the term "paroikia", which means to live next to something or in a foreign country, could be applied to the inhabitants of Sodom who were spared by the punishment [6].

\section{THE MEANING OF THE FOUR GROUPS OF ACTIVITIES}

Before analyzing the four groups of verbs, we may start with a prerequisite regarding Luke's predilection for presentations "two by two". In our case, verbs in verses 27-28 are used in groups of two, with reference to the basic areas of human existence.

\subsection{Food (verse 27): esthíô (to eat) and pinô (to drink)}

The term "esthío" is used in the New Testament in different contexts and with different meanings. Due to survival instinct, human beings make sure they have food and drink (Matthew 6:25; Mark 6:36). Such needs are often interpreted as actions to satisfy our hunger and quench our thirst or to have a feast (see Luke 17:8; 1Corinthians 11:21). However, the exaggerated search of food is inconsistent with the attitude of Jesus and of his disciples (see Mark 3:20;6:31). The group of actions "eating and drinking" could indicate joy and excitement, as well as a sign for a life dedicated to pleasure. This is a type of behavior many times disapproved by Jesus (see Luke 12:29; 
Matthew 24:29). Eating and drinking are human activities; Jews doubt that Jesus is God's messenger for the very reason that He eats and drinks with the sinners (Matthew 11:19).

The term "esthíô" is mentioned 33 times in the Gospel of Luke, while 11 times it is associated with the verb "pino". The meaning of such term in the New Testament is also present in the Gospel of Luke. However, it is worth mentioning the meaning of eating in Luke 17:26-28. The eschatological context, where the Parousia has not arrived, leads to a possible association with the parable of the wicked administrator, one who says to himself: "My lord delayeth his coming; and shall begin to eat and drink, and to be drunken" (Luke 12:45). In both texts, the verbs "to eat and drink" are joined by the conjunction "kai". Then, the actions are contrary to the advice of Jesus, that of not being concerned of what to eat and drink, as what matters is the search of the Kingdom of God (see Luke 12:29).

In the New Testament, the term "pinô" is used about 70 times (30 of which have no specific characteristic, while the other 40 times the term is in association with the verb "esthíô". As previously mentioned, eating and drinking are fundamental needs of the human being. However, there is the risk for these needs to lead to sin, when one abuses them. A modern idea, tributary to the gnostic ideas where the body is not worth anything, is that which says: "Let us eat and drink, because tomorrow we die!"” (1Corinthians 15:32).

Although food and drink are a continuous temptation for the human nature, one needs to fight against them, as Christian charity does not allow "eating and drinking" to become idols. This view is typical of paganism; Jesus always draws the attention of His people to the danger of complying with the mentality of this world that focuses too much on what to drink and eat (Luke 12:29). As regards Jesus and his disciples, the act of eating and drinking is carried out in liberty, regarding either the exaggeration in satisfying such needs or the methods of fasting practiced without the right spirit. Therefore, eating and drinking, as actions guaranteed by the grace of God, are performed for the glory of God and the love of neighbor.

Considering the Gospel of Luke, where "pino" is used 17 times, we need to question the meaning of this term in Luke 17:27-28. Looking at the eschatological context in which such term is present, where the Parousia is no longer anticipated, it can be mentioned that the action of drinking does not have a positive connotation. It is an excessive concern for food and drink, a criticized attitude as it leads to a humanly vision of life, so that the signs of the coming of the Kingdom are no longer visible. A comparison can be made between Luke 12:29 (as regards the concern for eating and drinking) and Luke 12:19 (where eating and drinking reflect the lack of interest for the Kingdom already inaugurated).

\subsection{Marriage (verse 27b): gaméô (to get married)}

In the New Testament, Jesus grounds the concept of marriage on the text in Genesis 2:24: man is united to his wife, and they become one flesh, as God created them (see Mark 10:8). The focus is on the unity of marriage. In the Gospel of Luke, the verb "gaméô" is used six times in five texts. Luke 16:18 takes marriage back to the origins intended by God, namely its unity and indissolubility. Luke 20:34-35 presents in antithesis the sons and daughters of this world who get married, and those of the afterlife who will have neither wife nor husband.

As regards the meaning of the action of getting married, in Luke 17:27 there could be a connection with Luke 20:34-35, considering we have a parallelism on two levels: on the one hand, the earthly life and, on the other hand, the afterlife. Furthermore, the two verbs relating to marriage also appear connected in Luke 17. The mention that in view of the imminent judgment it is necessary to refrain from having a spouse also suggests a probable connection with Luke 14:20. When being invited to the feast, someone answers: "I just got married, so I can't come!" This is contrary to Jesus' advice. To be His disciple, one has to hate one's parents, as well as one's wife and children (see Luke 14:26). Thus, Christ and following Christ come first, this being emphasized by the proximity of the Parousia. 


\subsection{Trade (verse 28a): agorazô (to buy) and poleô (to sell)}

In the New Testament, the verb "agorazô" usually means to buy, being rarely used to indicate commercial activities. The term is much more used to indicate the purchase and sale of slaves. In 1Corinthians 6:20 and 7:23, St. Paul speaks of Christ who bought us. These two fragments present Christians not as free people, but as slaves redeemed by the Savior. The term is clarified by the word "exagorazô" which implies re-purchase. The price paid for redemption is the very sacrifice of Christ, feely accepted out of love for us.

The meaning of "agorazô" in Luke 17:26-28 is undoubtedly that of buying, referring to trade relations. The verb is used six times by Luke, mainly with the common meaning. Generally, Jesus has a critical attitude with respect to trade. Jesus drives out those who are selling, those who have made the temple a den of robbers (Luke 19:45). In the parable of the guests invited to the feast, two people do not have time to attend because they have just bought a field or five yoke of oxen (see Luke 14:18-19). There were probably situations where commercial activities were given too much attention. Moreover, in Luke 13:19, Jesus does not agree with the disciples who wanted to go to buy food for the people. In this text, the act of buying is related to eating, as in Luke 17:28.

The term "poleô" is not frequently used in the New Testament; however, in the Gospel of Luke it is present six times. In the episode of the temple, besides those selling, Jesus also drives out those buying (see Luke 19:45). Often, selling does not imply a fair trade: one can sell five birds for nothing; however, everything has value before God; it is value that man cannot establish (Luke 12:6). Luke insists more on the need to sell and give everything to the poor to provide treasure in heaven (Luke 12:33; 18:22). Luke 22:36 includes the two verbs ("to buy and to sell") together, as part of Jesus' recommendations for the difficult times. Similarly, Luke 17:28 presents Jesus' vision on trade. Selling on earth has no value if there is no effort to buy the invaluable treasure of the Kingdom. He refers to the same two levels: the earthly life and the afterlife.

\subsection{Constructions and agriculture: oikodomeô (to build) and fyteuô (to plant)}

The term "oikodomeô" is used in several texts of the New Testament: to build a tower (Matthew 21:33), to build and tear down warehouses (Luke 12:18). The metaphorical meaning is used more often: Christ will build the new church, the heavenly one, by His resurrection (Matthew 16:18; Mark 13:27). The term also has an ecclesiological meaning, as the Acts refer to the Church built by God.

In the work of St. Luke, the verb "oikodomeô" is mentioned 12 times, being used more than by the others Synoptic authors. There is an allusion to building the house on a rock (Luke 6:48) or building a tower (Luke 14:28-30). However, there is also the metaphorical meaning, building the tombs of the prophets (Luke 11:47-48). As in Genesis 33:17, God does not condemn the action of building; however, this should not put man against God, as in the story of the Tower of Babel (Genesis 11:1-9).

The use of the verb in the present continuous in Luke 17:28 could be associated to Luke 12:18: in his desire to accumulate goods, the reckless rich man destroys the old barns to build larger ones. This is not a common action of building intended to satisfy the human needs, but rather an exaggerated construction activity. In the background, one can also see the action of "planting", as the rich man wants to store the wheat harvest. The purpose of the efforts of the rich man is then summarized in his desire to eat, drink and enjoy.

The verb "fyteuô" is less used in Luke's works. There is a reference to the fig tree planted in the vineyard (Luke 13:6) and to the vineyard planted by the master (Luke 20:9). At higher level, there is the judgment on faith which has the power to tell a tree to uproot and to plant itself into the sea. In this case, the action of planting has no connection with the agricultural activity, but rather with the power of faith.

Luke 17:28 could be related to the abovementioned fragments: the risk of focusing only on the human dimension, on agricultural activities which can be successful or unsuccessful, as is the case of the barren fig tree. This leads to ignoring or forgetting about faith. This solely has a higher 
power and renders humans capable of extraordinary things. Another conclusion is the connection between the agricultural activity and the actions of eating and drinking. Planting is the prerequisite to provide for oneself and one of the rules established by God in Genesis 3:19. Nevertheless, although it is the fruit of one's work, one should not abuse it.

Summarizing the analysis of such actions, we can reach some conclusions. If the act of eating and drinking can also be regarded as having a negative component due to a modern perspective on life, this is not true for the other activities (trade, constructions) in the case of which it is difficult to identify a negative component.

Fitzmyer notes that some of the verbs listed in Luke 17:26-30 are also used in other fragments of the author in order indicate distraction from what should be a proper human existence: to buy (Luke 14, 18, 19), to eat, drink and build (Luke 12:18-19), to sell (Luke 19-45) [7]. Despite their normality, these activities indicate a human existence characterized by indifference and negligence.

\section{THE MEANING OF THE ACTIONS AND THE EXHORATION OF THE EVANGELIST}

\subsection{The immanent vision on life (comparison with the days of Noah and Lot)}

In analyzing the text in Luke 17:26-30, we tried to identify the implications of the words that Jesus addressed to the disciples. In this context, many exegetes emphasize the exhortative function of the fragment: the advice addressed to the disciples to beware of obstacles and to be available on the day Jesus returns. Therefore, the comparison is not between the days of Noah and Lot and the days of the Parousia, but rather between the "facts happened in the days of Noah and what will be in the days of the Son of Man; Luke's exhortation interest is focused on behavior, namely the negligence of the people." [8]

Emphasis was placed on the actions performed by the contemporaries of Noah and Lot, which can be compared to those which will anticipate the days of the Son of Man. The author proposes a number of seven activities. In the Bible, seven symbolizes entirety. At the same time, we can say that it is a symbol of cyclicality: seven days of the week, repeated in cycle. Therefore, the seven activities listed by the author are the perfect total of the human activities, and could also indicate cyclicality and repetitive character.

Luke's writing cannot disregard the eschatological aspect dominant in the analyzed text. The final point of the resemblance to the days of Noah and Lot is the coming of the Son of Man. Furthermore, a text of the Talmud is significant from eschatological perspective: there will be no eating or drinking in the afterlife, no procreation or generation; there will be no envy or hate or fighting (Babylon Talmud, Berakot 17a). This text appears to be a faithful reflection of the one in Luke 17:26-30.

A number of prerequisites are necessary before taking into account the text on Noah in Genesis 6:1-12. First of all, the allusions to Noah in the Post-exilic books of the Old Testament are not many. At a later stage, references to Noah contain two ideas: his righteousness and the presentation of the flood as judgment of sinners. Noah and Lot are also mentioned in the New Testament, as in the case in 2Peter 2:5. They are considered "witnesses of God's grace, saved because they listened to God and look forward, not backward" [9].

If we compare Genesis 6:6-12 and Luke 17:26-27, we can identify some differences. A first aspect indicating a negative situation of disorder and moral chaos is the union between the sons of God and the daughters of men. Even if we referred to a mythological theme, on the one hand there is the human nature prone to sin, and on the other hand there is the sentence of judgment and destruction from God. Then, the biblical author states that man is just flesh, which is weakness (see Genesis 6:3). The wickedness of man is also emphasized, a negative trend and distortion of human nature, considering that "every inclination of the thoughts of the human heart was only evil" (Genesis 6.5). Consequently, God decides the destruction of all people, even all living beings, bringing human history to zero. Only Noah and his family will be saved, and a new history will start anew, in fact a new creation. 
Moving on with the observations, it could be said that all men are subject to God's judgment and all will be destroyed, as can be noticed in Luke 17:27. As regards the sins committed by Noah's contemporaries, we generally refer to proneness to evil, having as a starting point the union between the sons of God and the daughters of men. In a broader sense, we have at the forefront the idolatry and disobedience to the true God. Probably, the actions described in Luke 17:27 also indicate an unjust attitude towards God, a tendency not so much to evil but exclusively to earthly life.

Another relevant aspect is related to the episode where Noah drinks wine and gets drunk, thus exposing his son to his father's nudity. In this case, excessive drinking can have negative consequences, leading even to locating oneself outside God's blessing.

Finally, the fact that Genesis condemns the marriage between the sons of God and the daughters of men, that is association between the divine and the human, can have an extension in Luke 17:27.

The most significant difference between the text in Luke 17 and the one in the Genesis is the absence of any reference to sins in Luke's text. Luke is mostly referring to a lifestyle. He is not a moralist, but rather an eschatologist who wants to ground ethics on eschatological basis. Noah is not mentioned in Luke 17, as he is implicitly considered a righteous man; however, there is no mention to his contemporaries who committed bad deeds. Therefore, it can be said that the Gospel of Luke speaks of a life with no formal sins. In this case, Luke would give a revolutionary interpretation: ordinary actions are condemned. Thus, in Luke's vision, being focused exclusively on the earthly life and forget about the Parousia is a serious sin.

The story of Lot is described in Genesis 19. Sodom and Gomorrah are often mentioned in the Old Testament. If in the case of Noah and the flood the salvation is also mentioned, the rewritings on Sodom only refer to the sin. God decided to destroy Sodom and Gomorrah for the evil committed by the inhabitants of these cities. This situation seems more serious compared to Noah's times; in fact, the heart of the inhabitants of Sodom is permeated by evil, and there is an explicit indication, namely the desire to abuse the messengers of God. The consequence of sin and idolatry is God's judgment which annihilates all, apart from Lot and his daughters. In addition, the city is destroyed, together with the valley and its vegetation.

The story of Lot presents some similarities with Luke 17:29. Luke's text also mentions the total destruction; then, there is a worsening of the situation, the author listing six verbs that reflect human activities, thus extending the previous verses; furthermore, God's judgment destroys what was planted and built. Finally, the reference to the market in Genesis 19:2 is proof of the presence of trade activities routinely carried out in that area.

With respect to obtaining salvation, it is not permitted to look back, to return to the past; otherwise it can happen as in the case of Lot's wife.

At this point, we ask ourselves about the author's intention when mentioning the divine judgment and making the comparison with the days of Noah and Lot. If we take a more detailed look at the text, we notice that the evangelist does not condemn exaggerations or negative deeds. Furthermore, Luke does not mention about a possible punishment for the sins committed. He merely describes the common actions, making the transition from the ancient times to the day of the Son of Man. The evangelist probably wants to warn, to utter words that can be understood by those who want to understand. The exhortative intention of the author is rooted in the conception of the Old Testament where the flood and the destruction of Sodom are considered typical punishment of God.

From the perspective of the Gospel as a whole, one can conclude that Luke intends to condemn, first of all, an immanent vision on life. We could mention various reasons in favor of this idea. First, the long list of actions typical of the earthly life is already a sign in this direction. With this in mind, taking into consideration the hedonistic concept, Brown states that earthly pleasures, feasts and entertainment were encouraged, where eating and drinking prevailed. [10]

Then, the lack of any mention to actions relating to the religious dimension or indication of attention paid to God leads to the conclusion of a life guided solely by the worldly principles. Therefore, this very type of practical atheism is condemned by the evangelist. In other parts of the 
Gospel, Luke criticizes the greed that threatens the rich man (Luke 12:13-21), while the concern for the necessities of life, for natural needs (food, clothing) is likely to take control of the disciple (Luke 12:22-34). People expressing this kind of attitude can also be found in the parable of the sower, referring to those people controlled by worries, by the pleasures of life, who fail to bear mature fruit (see Luke 8:7).

To avoid such worries and a false certainty, it is necessary to trust God and to wait for the Kingdom. The secular vision on life is constantly criticized by Jesus who came to proclaim salvation and to be the eschatological prophet of the Kingdom of God.

\subsection{Lack of concern for the Kingdom of God}

At a second point, a consequence of the immanent vision on life is the lack of concern for the kingdom of God. Thus, there was the risk of losing the awareness that God is the master of all and giver of all good.

When referring to food ("to eat"), Israel often forgot that God is the master of all; however, the chosen people lived being aware that they were living in the presence of God, using His gifts. The idea is also expressed in Deuteronomy 12:7: "in the presence of the Lord your God, you and your families shall eat and shall rejoice in everything you have put your hand to, because the Lord your God has blessed you." This action of eating is essential to human existence and the relationship with God. There is a saying according to which man is what he eats. Therefore, if one consumes only earthly things, it will also be earthy; likewise, if it lives on the heavenly realities, it will never die.

Therefore, for all the right reasons, Luke wants to raise the interest for spiritual realities, for the Kingdom of God already present. The evangelist wants to be comprehensive, taking into account all areas of life: eating, drinking, getting married, as well as the aspects of social life: to sell and to buy, to plant and to build.

It has been mentioned several times that these activities are not negative in themselves; on the contrary, they stand for good things, being essential for human development, both at individual and social level. Therefore, we ask the same question: if these actions are not negative, why has God ruled his judgment upon these generations?

In Luke's writings, especially in the Acts, there are fragments where sin is punished with sudden death (see Acts 1:18; 5, 5:10). The Gospel also alludes to the mortal danger represented by the attachment to worldly goods and riches. This attitude will be punished on judgment day, as seen in Luke 12:46; 21:34-36. Judgment Day is the same as the one described in Luke 17:26-30, a day that will come unexpectedly and will destroy all.

Based on these prerequisites, one could identify the negative component of the apparently common actions listed by the evangelist. This negative component resides in: concern only for the things typical to the earthly life. Indeed, there is no allusion to the mind focused on God or on worshiping the divine. Such a vision projected solely horizontally cannot satisfy all the needs of the human nature inherently aspiring to the higher Being. To this end, Jesus rules a negative judgment: "man is a citizen of a world having as law the will of God; instead, man is law to itself, placing the satisfaction of its temporary needs, instincts and weaknesses, at the center of its existence" [11].

All this insistence leads to the idea of a poor Christian life where little space is given to God. This is in line with Zedda's finding: "the generation of Noah and Lot is considered negligent and, therefore, it is unexpectedly subject to divine judgment. This will also be the case of the generation that will witness the end of this world: they will live carelessly and with no attention to religion and, therefore, the Parousia will be a disaster for them" [12].

Then, knowing God and listening to the text of the Gospel, one cannot remain in an attitude of ignorance towards the heavenly realities. As in other sections of the Gospel, Luke 17 presents the negligence as concerns the arrival of the Parousia: "The Lord delays to come, so let us eat, drink, feast!" This is not the Christian attitude of a disciple of Christ called to be prepared for the coming of the Son of Man. The anticipation should also influence our behavior. Consequently, the realities 
of this life are relative and should not determine our existence to such an extent that we forget the ultimate goal, namely obeying the will of God so as not to not be destroyed, but rather saved.

\subsection{The delay of the Parousia and the torpor of the Christian life in the communities}

The above-mentioned considerations and the lack of anticipation of an imminent the Parousia can lead to the conclusion of certain torpor typical of the Christian life of Luke's communities. The cause of such attitude must be sought in the delay of the Parousia which led to people not preparing for the end. "Luke sees in his community the lack of attitude towards the Christian effort as regards the delay of the Parousia. Christians have returned to their daily occupations and concerns: eating, drinking and having fun, similarly to the generation in the times of Noah and Lot. They should be careful because the Son of Man will come like lightning." [13] It is not by accident that, in many parts of his gospel, Luke emphasizes that the kingdom of God is present, and insists on the necessity of conversion and of living as anticipation of the afterlife. This reduced effort in living a life in compliance with the gospel is also the result of the mentality typical to the Greek society which influenced Luke's community.

One question which might arise at this point is: what is the solution to avoid divine judgment which could punish Jesus' followers, as in the case of the contemporaries of Noah and Lot? One answer can be identified in Luke 17:33: "Whoever tries to keep their life will lose it, and whoever loses their life will preserve it." What is considered is this very effort to preserve and save the earthly life without thinking of the afterlife. This is typical for a community who does not anticipate the Parousia, who lives according to the Greek mentality and pays no attention to the kingdom of God. Therefore, the evangelist wants to teach the right way to interpret Christian life.

Later on, Luke 17:33 urges "to be ready and to leave everything when the Parousia arrives, even one's own existence, in order to be transformed by the afterlife. The reality of the eschatological coming of the Son requests the faithful to have a behavior contrary to the conduct of those focused exclusively on the worldly reality. The advice not to get attached to goods, the critical attitude regarding wealth throughout the Gospel has now found the eschatological motivation in Luke 17:33: to be ready for the coming of Christ which could happen at any time." [14] This preparation and readiness should not be based on a dull existence with no attention paid to God; on the contrary, it should be a life permeated by religious feelings. Luke insists on salvation which can only be achieved if man contributes to it.

The themes of conversion, prayer, renunciation of goods and liberation from earthly concerns are fundamental. On the one hand, Luke criticizes contrary situations while, on the other hand, he wants to genuinely train his disciples for an authentic observance. All this now has an eschatological motivation: being ready for the coming of the Son.

The preparation for salvation consists in repentance and conversion. According to the Acts, repentance and conversion prepare the glorious coming of Christ and the establishment of the end of times in the new world. Christians are anxiously waiting for the eschatological intervention, being convinced that the resurrection of Jesus prepares such intervention: "it renders the one making the final judgment partaker to its powers. This perspective now becomes a reason for conversion: all men, whether pagan or Jewish, are invited to prepare for judgment, by conversion and believing in the reigning of Jesus; it is only this way that they will be able to take part in the happiness of the afterlife." [15]

Luke is the theologian of salvation which man must strive to possess. However, to obtain salvation, one must also observe ethics. The moral imperative arises from the conflict between present and future, between reality and promise. The main reason of the moral message does not reside in the proximity of the end, as Jesus himself refused to indicate the date and place of the Parousia. Christ is more interested in the present; His main intention is to call people to conversion and faith; it is only at a second level that he refers to warnings. Thus, what matters more is salvation. At the same time, Luke wants to talk about a salvation which is already present. Apart from the statement in Luke 17:21: "the kingdom of God is in your midst", the evangelist insists on the "today of salvation" (see Luke 19:1-9; 4:21; 2:11). 


\section{CONCLUSION}

Starting from the text in Luke 17:26-30 which compares the days of the Son of Man with the days of Noah and Lot, the attention is focused mainly on the activities performed by those generations while neglecting the spiritual realities. The emphasis is placed on the fact that the actions described by the evangelist are not negative in themselves; nevertheless, the divine judgment arrives and condemns them.

A reason could be that Luke is not so much interested in the morality of such actions. Indeed, this idea can be noticed in several texts of the author, and one could be surprised to note that the evangelist makes no moral judgments on what certain characters think or do. This is the case of the parable of the rich man and Lazarus, the parable of the wicked rich man, and of the dishonest manager. However, the exasperated focus on the earthly realities, forgetting about God and the neighbor, is a negative aspect criticized by the evangelist.

We elaborated enough on eating and drinking as synonymous with a life made of pleasure. It seems that this was a favorite theme for Luke, as it makes references to it in several sections of the gospel. Some exegetes have shown the connection between the theme on eating and drinking and that on wealth. The rich are those who enjoy the pleasures of feasting, while the poor are almost always hungry (see the beatitudes, the parable of the rich man and of Lazarus). By inference, it could be said that the rich are the ones who not only eat, drink, but also build or plant, as seen in the parable of the wicked rich man. Probably, the actions of building and planting, as in the case of the contemporaries of Noah and Lot, corresponded to eating, drinking and enjoying oneself (similarly to the feeling in the heart of the wicked rich man).

Wealth and riches are not bad in themselves; however, experience has proved that these are often put to bad use. Wealth often leads to a life of pleasure and body satisfaction. Even if one does not show such behavior, insistence on obtaining material goods and wealth may be bad. In order to avoid this becoming an obstacle to obtain salvation and the afterlife, one needs to pray with faith, to attain conversion and to share one's goods with the poor.

The goods of this world are a constant danger to salvation. The rich are exposed to the danger of relying too much on wealth and of forgetting God. There is also a danger for the poor: they do not possess goods, but want to obtain them and can show concern and care to have something they can rely on. This could also be accounted for by the hedonistic mentality of a society like the Greek one. Jesus teaches the disciples not to behave as citizens of the world, who care about what they eat and drink.

Generally, Luke does not condemn wealth as such, but rather the obstacle it may become for conversion. The rich have a horizon which is so limited that they cannot see beyond it. Yet, the rich man can obtain salvation, as well: it is the case of Zacchaeus who gives half of his possessions to the poor, as well as the example of the dishonest manager who understood that it is essential to provide treasure in heaven and to secure a place in the Kingdom.

In addition, one can notice Luke's preference for exhortations. The text in Luke 17:26-30 is nothing but an exhortation addressed to the disciples, together with a warning for a righteous attitude as regards the coming of the Lord. Luke presents his readers the two exemplary punishments of the Old Testament: the flood and the destruction of Sodom, and urges to fair elections. This manner of expression of the evangelist aims at determining a lifestyle based on the eschatological anticipation, and draws the fundamental guidelines of his theology.

The analysis supports the idea that Luke is the theologian of salvation. What interests more is that Jesus' message lead to salvation. Therefore, this is the meaning of the exhortations of the Saviour (not to worry for the things of this world, to be on the watch in an attitude of prayer, so that the Lord may find them prepared). Attention to the afterlife seems to be a prerequisite and an essential request to attend one day the heavenly feast with Jesus Christ.

All the above leads to the idea of a perennial character of the gospel; the Gospel of Luke seems to be particularly true for our society, although the context is somewhat different. Currently, the difficulty resides in the anticipation of the Parousia, which for the early Christians represented a fundamental motivation for a coherent living of the faith, given the perspective of the judgment and 
of the rewarding related to Christ's coming in glory. For nowadays society, too, the anticipation of the Parousia must be active, as there will be an end. However, the focus is on the expectation of the blessed meeting with the Lord who comes. In view of this meeting, the goods and the activities of this world must represent means leading to a happy eternal life.

\section{References}

[1] J. Fitzmyer, The Gospel According to Luke (X-XIV), Doubleday, Garden City, 1985.

[2] G. Rossè, Il vangelo di Luca, Città Nuova, Roma, 1995.

[3] R. Schnackenburg, La vita cristiana, esegesi in progresso e in mutamento, Jaca Book, Milano, 1977.

[4] R. Meynet, Il vangelo secondo Luca. Analisi retorica, Edizioni Dehoniane, Roma, 1994.

[5] L. Sabourin, Il vangelo di Luca. Introduzione e commento, Piemme, Roma, 1989.

[6] J. Schlosser, Les jours de Noè et de Lot, Revue Biblique 80 (1973) 27-28.

[7] J. Fitzmyer, The Gospel According to Luke (X-XIV), Doubleday, Garden City, 1985.

[8] G. Rossè, Il vangelo di Luca, Città Nuova, Roma, 1995.

[9] K.H. Rengstorf, Il vangelo secondo Luca, Paideia, Brescia, 1980.

[10] S. Brown, Apostasy and Perseverance in the Theology of Luke, Roma, 1969.

[11] B. Corsani, L'uomo nelle parabole di Gesù, in: Associazione Biblica Italiana (ed.), L'uomo nella Bibbia e nelle culture ad essa contemporanee, Paideia, Brescia, 1977, p. 166.

[12] S. Zedda, L’escatologia biblica I, Paideia, Brescia, 1972.

[13] G. Segalla, Evangelo e Vangeli, EDB, Bologna, 1993.

[14] G. Rossè, Il vangelo di Luca, Città Nuova, Roma, 1995.

[15] J. Dupont, Studi sugli Atti, Paoline, Roma, 1971. 